\title{
The Influence of Competence and Work Motivation to Teacher Performance in Smp Negeri At Kota Kupang
}

\author{
*Jefirstson Richset Riwukore, University of Indo Global Mandiri, Jenderal Sudirman Street, KM-4, No.629, \\ Palembang, Sumatera Selatan, 30129, jefritson@uigm.ac.id \\ Fellyanus Habaora, Post Graduate, Animal Science and Technology Production, Bogor Agricultural University, \\ Raya Dramaga Street, Kampus IPB Dramaga Bogor, 16680, Jawa Barat \\ *Corresponding Author
}

\begin{abstract}
The low and poor quality of education in Indonesia is an indicator of the inadequacy performance of educational resources such as teachers in Indonesia. One region that can be studied related to the human resource aspect of education is teachers at Junior High Schools (SMP) in Kupang City, East Nusa Tenggara Province (NTT). The purpose of this research was to determine the effect of competence and work motivation on the performance of teachers in SMP Negeri in Kupang City. This research uses quantitative as sociative methods from the independent variables (competence or motivation) to the dependent variable (performance). The types of data used are data of primary and secondary. The technique of obtaining data is carried out through interviews, observation, and documentation. The research population was 447 people who were determined by purposive stratified proportional sampling to be 45 respondents. The data analysis used statistical multiple linear regression analysis with the SPSS 20.0 application. The research results showed that partially and simultaneously, the variables of competency (0.332 units) and motivation (0.291 units) had a positive value and had a very significant effect on the performance of the teachers of SMP Negeri in Kupang City. The results of this research can be used as recommendations for school heads, department heads, and policymakers to improve the quality of education output by providing motivation and increasing the competence of teachers.
\end{abstract}

Keywords: competence, work motivation, teacher performance. Received: $19.11 .2020 \quad$ Accepted: 26.12.2020

Published: 17.01.2021

\section{INTRODUCTION}

One of the national development indicators is the human development index (HDI). HDI in Indonesia is still categorized as problematic, based on a report from the United Nations Development Program / UNDP (2016) that the Indonesian human development index (HDI) value only reached 0.689 or is ranked 113th out of 188 countries. The HDI value has decreased from the previous rank, namely, among 174 countries in the world, Indonesia ranks 102 ${ }^{\text {nd }}(1996), 9^{\text {th }}(1997), 105^{\text {th }}(1998)$, and 109 th $(1999)$. One of the factors affecting the low and concerning poor HDI score in Indonesia is the quality of education. The Survey Report of Political and Economic Risk Consultant (PERC) states that the quality of education in Indonesia ranks $12^{\text {th }}$ out of 12 countries in Asia, or does not increase from the report of The World Economic Forum Sweden (2000) that Indonesia is only predicated as followers not a technology leader from 57 countries because Indonesia only ranks $37^{\text {th }}$ based on the competitiveness index. Likewise, the report of the United Nations Educational, Scientific and Cultural Organization (UNESCO) in 2016 in the Report Global Education Monitoring (GEM) 2016 states that education in Indonesia is ranked $10^{\text {th }}$ out of 14 developing countries. Riwukore, Susanto, Manafe, Habaora, \& Miramangngi (2019) stated that the quality of education is also determined by the competence and motivation of teachers to improve their performance on education development in Indonesia. Based the aspect of competence, teachers in Indonesia may not fulfill the expected competencies. The Indonesian Ministry of Education and Culture (2015) reports the results of the teacher competency test (UKG) in Indonesia as a national average of only 44.5 or far below the standard value of 55 . Generally, teachers in Indonesia still teach only text books and boring teaching in class without creativity. The condition of Indonesia's education will get worse because teachers still have low motivation. One of the factors that reduce teacher motivation to express and innovate in improving performance is appreciation from aspects of both material and immaterial. For example, Sukarana, Dantes, \& Dantes (2015: 10) report that there are 
differences in work motivation between certified teachers and non-certified teachers, there are differences in performance between certified teachers and non-certified teachers, there are simultaneous differences on motivation work and performance between certified teachers and non-certified teachers.

Poor education in Indonesia, poor quality of teachers, and low competitiveness of educational outcomes are the accumulation of complex educational problems. The government continues to improve the quality of education in Indonesia by improving the education system in terms of management, curriculum, evaluation system, and society. One of the main goals of improving the quality of education is increasing the competence and motivation of teachers toward improve their performance. Sukidjo (2014) states that Law Number 14 of 2005 concerning Teachers and Lecturers is clear evidence of the government's seriousness in improving the quality of education, especially in terms of professionalism and teacher welfare. The consequence of teachers as professionals is that they continually improve their competence in order to improve the quality of learning in particular and the quality of national education in general. Teacher competence in question is pedagogical competence, personality competence, social competence, and professional competence which are all integrated in teacher performance (Novauli, 2015:49; Jabri, 2017:62). Danila \& Riwukore (2019:42-43) states that competence is a display of personal ability to complete various tasks based on the responsibilities received in certain situations or tasks that are carried out. Zamzam, Satria, \& Riwukore (2018:211) states that the existence of competence can increase motivation to succeed in a task, so that motivation is something that raises enthusiasm or work motivation. Next, Riwukore (2010:241-243) states that motivation and competence have a significant effect on improving individual work, which is defined by Susanto, Riwukore, Riance, Sardiyo, \& Habaora (2020: 3593) as performance, which is something achieved, demonstrated achievement, or someone's work ability.

Based on the description above, strategies to improve the quality of education in Indonesia can be carried out by increasing teacher competence and motivation so that it has an impact on teacher performance which affects educational output, namely the intelligence of students in a school. Fajri, Rahman, \& Lisnawati (2019:265) reported that there is a positive relationship between teacher performance and student achievement with a correlation coefficient of 0.6916 and a coefficient of determination of 0.4783 , which means that $47.83 \%$ of student achievement can be resulted from teacher performance. Togatorop \& Heryanto (2019) reported that $79.12 \%$ of student learning success was strongly influenced by the good performance category of teachers with an average score of 105.83. Hill \& Chin (2018) states that teacher performance affects the increase in student learning outcomes scores. This means that the greater the teacher's performance in planning, implementing, and evaluating learning, the greater the opportunity for the teacher to improve student learning achievement, and the teacher's teaching experience contributes to improving student learning outcomes. The aspect of teacher performance is influenced by many factors, including the motivation and competence of the teachers. Rasto \& Maulani (2019) stated that satisfaction and motivation have a positive and significant influence on teacher performance, either partially or simultaneously. The research concluded that the teacher's performance can be improved by improving the satisfaction and motivation. Nor, Embong, Muda, Yunus, \& Nor (2019) reported that there is a positive and significant relationship between teacher competence in carrying out teaching scientific assignments to improving student performance and learning achievement.

The quality of education in Indonesia, which is still low and categorized as poor, is an indicator of the inadequacy of educational resources such as teachers in various regions in Indonesia. One area that can be studied in relation to aspects of motivation and competence on performance is teachers in Junior High Schools (SMP) in Kupang City. Nagul, Yusuf, \& Syahniar (2013) reports that there are still a large proportion of teachers in Kupang City with a variation between $14.41 \%-18.43 \%$ who have not shown good performance in terms of task implementation and motivation in schools. In addition, it was reported that the effect of motivation simultaneously with teacher perceptions of performance only affected $28.55 \%$, which is possible that there are many other factors such as competence that also affect the performance of teachers in Kupang City. The East Nusa Tenggara statistical report (2020) reports that the average HDI of NTT is growing slowly from 63.73 in 2017 to 65.23 in 2019, or is still below the national average of 71.92 . This indicates that the province of NTT needs improvement in education performance, including educational resources such as competence and motivation of teachers. The existence of Kupang City as a barometer for the central city of NTT province from the results of the performance of the teaching staff is expected to be a stimulus for improving the performance of teachers in the province, and Indonesia in generally. Riwukore \& Habaora (2019a) states that performance improvement is the transformation of the current performance display to a better state in the future after knowing the current performance conditions. Based on this description, the 
purpose of carrying out the research is to understand and know the effect of competence and motivation on teacher performance with a case study on teachers of Junior High Schools of State in Kupang City. The research location was chosen by purposive sampling because it was easier to access information and data from the research subjects, and Kupang City was the barometer for the province of NTT. The BPS report (2020) states that the HDI of Kupang City is better than the districts / cities in NTT with a value of 79.55, meaning that the City of Kupang is the reference for research results on other districts / cities that have HDI values that are still below Kupang. Based on the background, the problem formulation and hypothesis development in this study are: (1) competence (X1) significant effect on teacher performance (Y); (2) work motivation (X2) significant effect on teacher performance (Y); and (3) competence (X1) and motivation (X2) significant effect on teacher performance $(Y)$.

\section{METHODS}

This research was conducted for 6 months, starting from September 2019-February 2020 in Kupang City, East Nusa Tenggara Province. The determination of the population in this study is in accordance with the instructions of Sugiyono (2017), that population is an area of generalization consisting of objects or subjects that have certain qualities and characteristics determined by the researcher for study and then draw conclusions. The population in this study were 447 State Junior High School teachers in Kupang City, East Nusa Tenggara, from all teaching backgrounds. Based on the study population, data was collected only on $10 \%$ of the population to be used as sampling based on the purposive stratified proportional sampling method (Sugiyono, 2017) so that the sampling in this study was 44.7 or 45 research respondents.

The type of data used in this research is qualitative and quantitative data obtained from primary data and secondary data as supporting data for this study. Primary data is data obtained from direct sources, such as data obtained from distributing questionnaires filled in by respondents, while secondary data is data obtained from literature and processed data such as previous studies, journals, and collected articles. from searches on the internet relevant to the research. Sources of data through distributing questionnaires and observations. Questionnaire, data collection is done by distributing a list of questions to respondents. This questionnaire is intended to obtain respondents' answers about informative competence and motivation on performance of teachers in public junior high schools in Kupang City, East Nusa Tenggara.

The definitions of operational boundaries and variables in this informative study are the competence and motivation of teacher performance at SMP Negeri in Kupang City. Operational limitations and variables according to Sujarweni (2014) are things that are determined by the researcher to study so that information is obtained about them, and then conclusions are drawn. The data analysis used in this study is multiple linear regression analysis using the SPSS 22 for Windows application to determine the effect of each independent variable on the dependent variable, either together (simultaneously or partially) with the formulation according to Sugiyono (2017), namely as follows.

$Y=a+\beta_{1} X_{1}+\beta_{2} X_{2}$

Information:

Y : Teacher performance variables

a : Constant

$\beta_{1}:$ Teacher competency variable regression coefficient

$\beta_{2}:$ Teacher work motivation variable regression coefficient

$\mathrm{X}_{1}$ : Teacher competency variable

$\mathrm{X}_{2}$ : Teacher work motivation variable

\section{RESULTS AND DISCUSSION}

\section{Results}

Multiple linear regression or multiple linear regression is a linear regression model involving more than one independent variable or predictor. Based on this, multiple linear regression tests were carried out with the competency and motivation variables for performance, as presented in Table 1. 
Table 1. Multiple linear regression test

\begin{tabular}{|c|c|c|c|c|c|c|}
\hline \multicolumn{7}{|c|}{ Coefficients $^{\mathbf{a}}$} \\
\hline \multirow{2}{*}{\multicolumn{2}{|c|}{ Model }} & \multicolumn{2}{|c|}{ Unstandardized Coefficients } & \multirow{2}{*}{\begin{tabular}{|l|} 
Standardized Coefficients \\
Beta \\
\end{tabular}} & \multirow{3}{*}{$\begin{array}{l}\mathrm{t} \\
3.027 \\
\end{array}$} & \multirow{3}{*}{$\begin{array}{l}\text { Sig. } \\
.004\end{array}$} \\
\hline & & $\mathrm{B}$ & Std. Error & & & \\
\hline \multirow{3}{*}{1} & (Constant) & 26.790 & 8.577 & & & \\
\hline & Competence & .332 & .128 & .361 & 2.722 & .009 \\
\hline & Work Motivation & .291 & .053 & .380 & 3.022 & .004 \\
\hline
\end{tabular}

Source: Primary results processed by the SPSS 22 for windows program, 2020

From the processed SPSS 22, it can be seen that the results of multiple linear regression testing from the equation $Y=a+\beta 1 X 1+\beta 2 X 2$ are $Y=26,790+0.332+0.91$. Based on the results of the multiple linear regression test, it can be explained that the constant value is 26.790 , meaning that if the competency and work motivation variables do not change or the value is zero, then the value of the teacher performance variable is 26.790 . The coefficient value of the competency variable based on the results of the multiple linear regression test is known to be the value of 0.332 units, which means that if the competency variable value increases by one unit, the competency variable value will change positively by 0.332 units, and vice versa if the competency variable decreases by one unit then Teacher performance is also predicted to decline by 0.332 units because the results of multiple linear regression tests show that competence has a unidirectional relationship to teacher performance.

Hypothesis testing is used to determine and understand the relationship between competence and motivation, both partially and simultaneously, on teacher performance at public junior high schools in Kupang City. The test results of the hypotheses are presented in Table 2. Based on the information and data in Table 2, the obtained Fcount is 10.280 $>3.32$ Ftable, and the simultaneous significance level is $0.000<(\sigma)=$ $0.05, d f=n k=45-2-1=42$ is 3.32 , so that $\mathrm{H} 0$ is rejected and $\mathrm{H} 1$ is accepted, meaning that together (simultaneously) the independent variables, namely competence and work motivation, have a significant effect on the dependent variable, namely teacher performance so that $\mathrm{H} 1$ can be accepted and proven to be true.

Table 2. Testing of the hypothesis

\begin{tabular}{|c|c|c|c|c|c|c|}
\hline \multicolumn{7}{|c|}{ ANOVA } \\
\hline \multicolumn{2}{|c|}{ Model } & Sum of Squares & $\mathrm{df}$ & Mean Square & $\mathrm{F}$ & Sig. \\
\hline \multirow[t]{3}{*}{1} & Regression & 295.994 & 3 & 142.997 & 10.280 & $.000^{\mathrm{a}}$ \\
\hline & Residual & 588.583 & 42 & 13.776 & & \\
\hline & Total & 884.577 & 44 & & & \\
\hline \multicolumn{7}{|c|}{ a. Predictors: (Constant), Work Motivation, Competence } \\
\hline \multicolumn{7}{|c|}{ b. Dependent Variable: Teacher Performance } \\
\hline
\end{tabular}

Source: Primary results processed by the SPSS 22 for windows program, 2020

\section{DISCUSSION}

Based on the regression coefficient value of the work motivation variable of 0.291 units, it shows that if the value of the work motivation variable increases by one unit, the value of the work motivation variable will change positively by 0.291 units, and vice versa if the regression value decreases by one unit, it is predicted that there will be a decrease in teacher performance by 0.291 units because work motivation has a unidirectional relationship to teacher performance. The results of this multiple linear regression test are in accordance with research reports from Nagul, Yusuf, \& Syahniar (2013) and Nor, et al. (2019) stated that teacher motivation and competence have a positive and significant relationship to teacher performance. Meirina (2013) states that organizations/institutions must increase employee motivation to get maximum results and meet set targets. Fathurrochman (2017) states that the competence of an individual is something inherent in him that can be used to predict his level of performance which includes motives, self-concept, traits, knowledge, and abilities/expertise. Riwukore (2010) states that work motivation that needs attention to improve performance includes security, social, self-esteem, autonomy, and self-actualization, and types of 
competencies that need to be improved such as the ability to plan and implement (achieve), serve, lead, manage, think, and act mature. All of these things will automatically increase the performance of the teacher. Based on the descriptions stated, it can be concluded that competence and motivation have a positive and significant relationship to teacher performance. If one of the supporting components of teacher performance is negative, it will reduce teacher performance.

Based on Table 1, the results of the t-test show that the competency variable (X1) on the performance of teachers in SMP Negeri in Kupang City shows a tcount value of 2.722> a ttable value of 3.32 with a significance level of $0.000<(\sigma) 0.05, d f(n-2) 45-2=43$ is 3.32. This shows that H0 is rejected and H1 is accepted and partially the competency variable has a significant effect on teacher performance in public junior high schools in Kupang City. The results of this study are in accordance with those stated by Komang, Haris, \& Meitriana (2016) that simultaneously the elements of teacher competence such as pedagogic, professional, social, and personality competencies have a significant effect on teacher performance which is concluded from the results of the value analysis Fcount $=46.636>$ Ftable $=2.740$ and indicated by the $F$ test probability value of 0.000 smaller than $\alpha=0.05$ and the coefficient of determination of 0.726 or $72.6 \%$ of teacher performance is influenced by teacher competence. The results of this study are different from those reported by Chandra, Lie, Butarbutar, \& Efendi (2014) that the high and low or the ups and downs of teacher performance as much as $46.24 \%$ can be explained by teacher competence, and other factors can be explained by teacher motivation. The difference in the results of this study is strongly influenced by the correlation of motivation and competence which both have a significant effect on teacher performance. With competence, teacher performance can be more effective in completing assignments and then responsible for carrying out their duties properly (direction). The results of this study support the competency model stated by Riwukore (2010) that competence has a causal relationship if it is associated with employee performance. Competence consists of personal characteristics (motive, character, self-concept, and knowledge) which are expected to predict a person's behavior so that it can produce more optimal performance. The results of this study also support the statement of Susanto, et al. (2020) that competence refers to the characteristics underlying behavior that describes the motives, personal characteristics, self-concept, values, knowledge, or skills that a person who performs excellently in the workplace. The role of school heads and department heads or policymakers is very important in increasing the competence of teachers. This role is closely related to leadership competence. Leadership competence will improve performance management because it will increase the cooperation between leaders and employees (teachers) so that they can work effectively by developing knowledge, skills, and expertise. This collaboration will improve the performance of employees (teachers) by increasing the ability of employees to empower each member of the organization and make each member an important part of the success of the team (Riwukore, 2010: 225-226).

Based on Table 1 about the results of the t test that the work motivation variable (X2) on teacher performance shows the value of tcount $=3.022>$ ttable 2.091 with a significance level of $0.000<(\alpha) 0.05, d f(n$ 2) $31-2=29$ is 2.091 . This shows that $\mathrm{H} 0$ is rejected and $\mathrm{H} 2$ is accepted and partially the work motivation variable has a significant effect on the performance of state junior high school teachers in Kupang City. The results of this study are as reported by Ardiana (2017: 14) that work motivation has a positive effect on teacher performance with a contribution of $80.6 \%$ and other factors such as competence. The results of this study are also in accordance with Djafar \& Nurhafizah's (2018) report that the variable X (motivation) on Y (performance) is positive and has a significant effect with a tcount value of 4.1 while ttable is 2.021 for a significance level of 5\%, which means motivation and performance have correlation. Riwukore (2010) reports the results of his research based on the results of the AMOS analysis that motivation has a positive and significant effect on performance with a loading value of 0.387 and a critical ratio value of 2.347 is greater than 1.96, which means that a person's motivation to work more actively in improving their performance is an effort to get an award and in order to avoid punishment or dismissal. Habaora (2015) and Riwukore \& Habaora $\left(2019^{\mathrm{b}}\right)$ state that it is not easy to become a teacher who is able to produce quality graduates because it takes hard work to produce learning that is oriented towards the development of the potential of students. In this case, teachers who have good teaching performance are needed, because teaching performance reflects that a teacher has been able to fulfill his obligations responsibly as a professional. Motivation is an effort that can encourage someone to take the desired action, as a motive and a person's motive for action, because a person's behavior tends to be goals and is driven by the desire to achieve certain goals (Fernet, Guay, Senécal, \& Austin, 2012). The same thing is expressed by Aamir, Jehanzeb, Rasheed, \& Malik (2012) that motivation is seen as an impetus that encourages behavior, and underlies the tendency to survive. The motivation in question generally consists of 5 levels according to Abraham Maslow, namely 
physiological needs, security needs, the need to feel belonging, the need for self-esteem, and the need for selfactualization (Mangkunegara, 2017: 94). Zamzam, Satria, \& Riwukore (2018) stated that motivation to be affiliated in improving organizational performance can be influenced by the work climate and organizational career. This means that work climate affects affiliation motivation, and career development has a positive and significant impact on affiliation motivation, and simultaneously work and career climate affects affiliation motivation. The role of teacher leaders such as school principals and department heads or policy makers to always motivate teachers to achieve good performance is needed.

Based on Table 2, hypothesis testing is obtained that the Fcount obtained is 10.280> 3.32 Ftable and the level of significance that simultaneously or together competence and work motivation have a significant effect on the dependent variable, namely teacher performance. The results of this study are consistent with the results of research reported by Riesminingsih (2013) that the competence and motivation of teachers have a significant effect on teacher performance with a simultaneous contribution of $51.9 \%$. Therefore, school principals, heads of offices, and / or policy makers towards SMP Negeri teachers in Kupang City continue to maintain this condition so that teacher performance has an impact on improving student achievement in academics. The correlation between competence and motivation on performance was also reported by Tanius (2018) from the results of the regression equation $\hat{Y}=3.078+0.513 X 1+0.429 X 2$ that the contribution of teacher competence and motivation to teacher performance can reach $75.4 \%$ with a value of Fcount 133.61> Ftable 3,08 . A teacher has a very important role in managing students because the ways and actions of work motivation that will be carried out by the teacher ultimately have an effect on performance in carrying out their work. Work motivation is the giving of the driving force that creates someone's excitement so that they are willing to cooperate, work effectively, and be integrated with all their efforts to achieve satisfaction. Work motivation is an asset in mobilizing and directing employees or workers so that they can carry out their respective duties in achieving goals with full awareness, enthusiasm, and responsibility (Winbaktianur \& Putri, 2017). Teacher performance will be better if they have competence, which is the ability to carry out or do a job or task based on skills and knowledge and support by the work attitude demanded by the job (Mahdane, Hubeis, \& Kuswanto, 2018).

Fajri, Rahman, \& Lisnawati $(2019: 265)$ reported that there is a positive relationship between teacher performance and student achievement with a correlation coefficient of 0.6916 and a coefficient of determination of 0.4783 , which means that $47.83 \%$ of student achievement can be resulted from teacher performance. Togatorop \& Heryanto (2019) reported that $79.12 \%$ of student learning success was strongly influenced by the good performance category of teachers with an average score of 105.83 . Hill \& Chin (2018) states that teacher performance affects the increase in student learning outcomes scores. This means that the greater the teacher's performance in planning, implementing, and evaluating learning, the greater the opportunity for the teacher to improve student learning achievement, and the teacher's teaching experience contributes to improving student learning outcomes. The aspect of teacher performance is influenced by many factors, including the motivation and competence of the teachers. Rasto \& Maulani (2019) stated that satisfaction and motivation have a positive and significant influence on teacher performance, either partially or simultaneously. The research concluded that the teacher's performance can be improved by improving the satisfaction and motivation. Nor, Embong, Muda, Yunus, \& Nor (2019) reported that there is a positive and significant relationship between teacher competence in carrying out teaching scientific assignments to improving student performance and learning achievement.

\section{CONCLUSION}

Based on the results of multiple linear regression analysis, it can be concluded that the variables of competence and work motivation on the performance of teachers of SMP Negeri in Kupang City, simultaneously or partially have a positive and very significant effect. Indicators of the influence of teacher competence and motivation on teacher performance that are positive and have a significant effect can be a strategy in improving the quality of education in Kupang City, including in the Province of East Nusa Tenggara.

\section{CONFLICT OF INTEREST}

We do not have a conflict of interest with anyone in carrying out this research. 


\section{REFERENCE}

Aamir, A., Jehanzeb, K., Rasheed, A., \& Malik, O. M. (2012). Compensation methods and employees motivation (with reference to employees of National Commercial Bank Riyadh). International Journal of Human Resource Studies, 2(2), 221-230.

Ardiana, T. E. (2017). The effect of teacher work motivation on the performance of accounting teachers in SMK in Madiun City. Jurnal Akuntansi dan Pajak, 17(2), 14-23.

Chandra, F., Lie, D., Butarbutar, M., \& Efendi. (2014). The influence of teacher competence on teacher performance at the Kalam Kudus i-Learning Pematangsiantar Christian Elementary School. SULTANIST: Jurnal Manajemen dan Keuangan, 2(1), 1-8. doi:https://doi.org/10.37403/sultanist.v2i1.27

Danila, \& Riwukore, J. R. (2019). Pengaruh kompetensi dan motivasi terhadap kinerja pegawai di Dinas Pekerjaan Umum Bina Marga Provinsi Sumatera Selatan. Jurnal Ecoment Global, 4(2), 39-51.

Djafar, H., \& Nurhafizah, N. (2018). The influence of motivation of school heads on the performance of teachers and employees at SMK Muhammadiyah 3 Makassar. Jurnal Idaarah, 2(1), 24-36.

Fajri, A., Rahman, I. K., \& Lisnawati, S. (2019). Relationship between teacher performance with student achievement. The Annual Conference on Islamic Education and Social Science, 1(2), 260-266. Retrieved November 2020, 9, from http://pkm.uika-bogor.ac.id/index.php/ACIEDSS/article/view/508

Fathurrochman, I. (2017). Competency development of the State Civil Apparatus (ASN) of Islamic College employees (STAIN) through education and training methods. Jurnal Manajer Pendidikan, 11(21), 120129.

Fernet, C., Guay, F., Senécal, C., \& Austin, S. (2012). Predicting intraindividual changes in teacher burnout: The role of Perceived work environment and motivational factors. Teaching and Teacher Education, 28(4), 514-525. doi:10.1016/j.tate.2011.11.013

Habaora, F. (2015). Opinion population in abuse of power (Populasi opini penyalahgunaan kekuasaan). Yogyakarta, Indonesia: Deepublish Press.

Hill, H. C., \& Chin, M. (2018). Connections between teachers' knowledge of students, instruction, and achievement outcomes. American Educational Research Journal, 55(5), 1076-1112. doi:10.3102/000283121876961

Jabri, U. (2017). The profile of English Teachers' profesional competence and students' achievement at SMA Negeri 1 Enrekang. Edumaspul: Jurnal Pendidikan, 1(2), 61-77.

Komang, S. C., Haris, I. A., \& Meitriana, M. A. (2016). The effect of teachers' competence to teacher performance of SMPN 6 Singaraja. Jurnal Program Studi Pendidikan Ekonomi Undiksha, 7(2), 1-12. doi:http://dx.doi.org/10.23887/jjpe.v7i2.7802

Mahdane, A., Hubeis, M., \& Kuswanto, S. (2018). The influence of SKKNI and HR competencies on HR development in the HR Professional Unit in facing the MEA era. Jurnal Manajemen Pengembangan Industri Kecil Menengah, 13(1), 1-9.

Mangkunegara, A. P. (2017). Manajemen sumber daya manusia (Cetakan Ketiga ed.). Bandung: Alfabeta Press.

Meirina, Y. (2013). The influence of job satisfaction, work environment and work motivation on employee performance in the Industrial and Energy Division of PT Haskoning Indonesia. MIX: Jurnal Ilmu Manajemen, 3(3), 322-332.

Nagul, W., Yusuf, A. M., \& Syahniar. (2013). The perception of task and work motivation influencing much on the performance of BK Teacher/Counselor at Junior High Schools in Kupang City. Jurnal Konseling dan Pendidikan, 1(3), 1-8.

Nor, N. M., Embong, R., Muda, H., Yunus, K., \& Nor, J. M. (2019). Effects of teachers' teaching competencies on students' academic performance mediated by holistic centered learning style based on SUMUR Program at Secondary Religious Schools. International Journal of Academic Research in Progressive Education and Development, 8(2), 25-38. doi:10.6007/IJARPED/v8-i1/5600

Novauli, M. F. (2015). Teacher competence in improving learning achievement at SMP Negeri of Kota Banda Aceh. Jurnal Administasi Pendidikan Pascasarjana Universitas Syiah Kuala, 3(1), 45-67.

Rasto, \& Maulani, S. Y. (2019). Satisfaction and motivation as determinants of teacher performance. Jurnal Pendidikan Bisnis dan Manajemen, 5(1), 11-21. doi:http://dx.doi.org/10.17977/um003v5i12019p011

Riesminingsih. (2013). The influence of teacher's competency and Motivation to the teacher's performance in Yadika 3 Senior High School. MIX: Jurnal Ilmu Manajemen, 3(3), 263-271. 
Riwukore, J. R. (2010). Effect of transformational leadership, competency motivation and commitment to work organization and performance of employees in Goverment Secretariat City Kupang, East Nusa Tenggara [Disertasi]. Surabaya: Program Doktor Ilmu Ekonomi, Program Pascasarjana, Universitas 17 Agustus 1945.

Riwukore, J. R., \& Habaora, F. (2019). Expenditure display of education cost on households in Kota Kupang and the policy of masterplan. International Journal of Innovative Science and Research Technology, 4(7), 93-99.

Riwukore, J. R., \& Habaora, F. (2019). Perception of farmers on the performance of extensionist in the pasture agroecosystem of Timor Tengah Utara District. Asian Journal of Agricultural Extension, Economics \& Sociology, 29(2), 1-10. doi:10.9734/AJAEES/2019/45539

Riwukore, J. R., Susanto, Y., Manafe, H., Habaora, F., \& Miramangngi, S. (2019). Posture analysis of regional budget (APBD) and regional budget for education in Kota Kupang. Jurnal Penelitian Kebijakan Pendidikan, 12(2), 182-192.

Sugiyono. (2017). Methods of quantitative, qualitative and combination writing (mixed methods). Bandung, Indonesia: Alfa Beta Press.

Sukarana, K., Dantes, N., \& Dantes, G. R. (2015). Motivasi kerja dan kinerja guru ditinjau dari status sertifikasi pada guru-guru se-kecamatan Abang tahun pembelajaran 2013/2014. e-journal Program Pascasarjana Universitas Pendidikan Ganesha: Program Studi Pendidikan Dasar, 5, 1-10.

Sukidjo. (2014). Junior high school teachers' competence in conducting class room action research. Cakrawala Pendidikan: Jurnal Ilmiah Pendidikan, 33(3), 368-378. doi:https://doi.org/10.21831/cp.v3i3.2381

Susanto, Y., Riwukore, J. R., Riance, A., Sardiyo, \& Habaora, F. (2020). The effect of complexity of the competence independence task on integrity of the implication in the quality result auditor examination in North Musirawas District. International Journal of Scientific and Technology Research, 9(4), 35913597.

Tanius, N. (2018). The influence of competence and work motivation on teacher performance at The Bethel Christian Foundation Jakarta. JENIUS: Jurnal Ilmiah Manajemen Sumber Daya Manusia, 1(3), 1-12. doi:http://dx.doi.org/10.32493/JJSDM.v1i3.1288

Togatorop, J. B., \& Heryanto. (2019). The effect of teacher performance on student learning outcomes Public Elementary School 060934 Medan Johor Academic Year 2017/2018. International Journal of Education, Learning and Development, 7(5), 97-107.

Winbaktianur, \& Putri, N. U. (2017). The effectiveness of motivation training to increase the work motivation of outsourcing workers as cleaning service at UIN Imam Bonjol Padang. Konseli: Jurnal Bimbingan dan Konseling, 4(2), 65-80.

Zamzam, F., Satria, C., \& Riwukore, J. R. (2018). Meningkatkan motivasi berafiliasi pegawai Sekretariat Dewan Perwakilan Rakyat Daerah Kabupaten Se Sumatera Selatan. Jurnal Ecoment Global, 3(2), 208-222. 